Esta publicación cientifica en formato digital es continuidad de la revista impresa ISSN-Versión Impresa 0798-1406 / ISSN-Versión on line 2542-3185Depósito legal pp
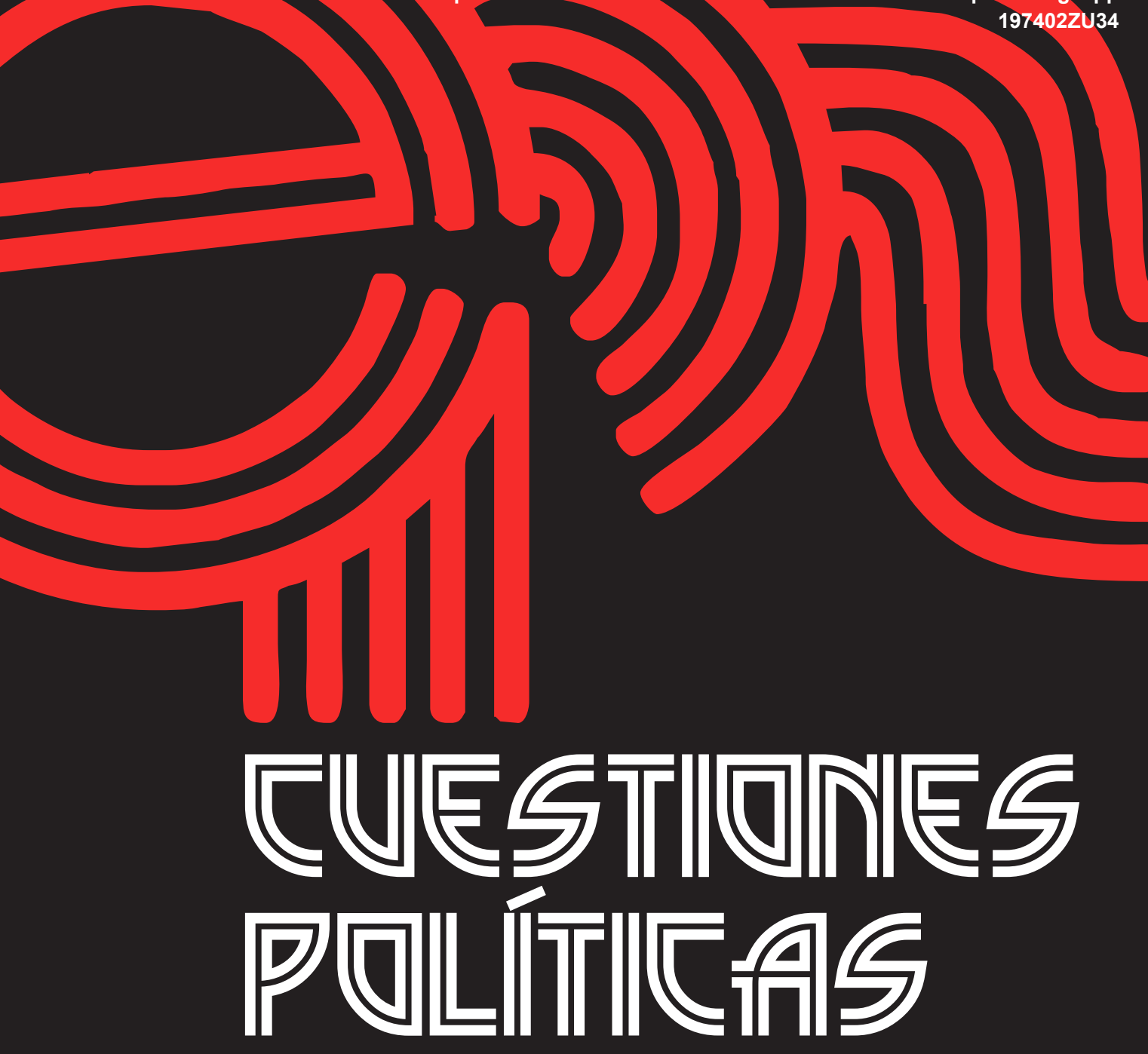

Instituto de Estudios Políticos y Derecho Público "Dr. Humberto J. La Roche" de la Facultad de Ciencias Jurídicas y Políticas de la Universidad del Zulia Maracaibo, Venezuela
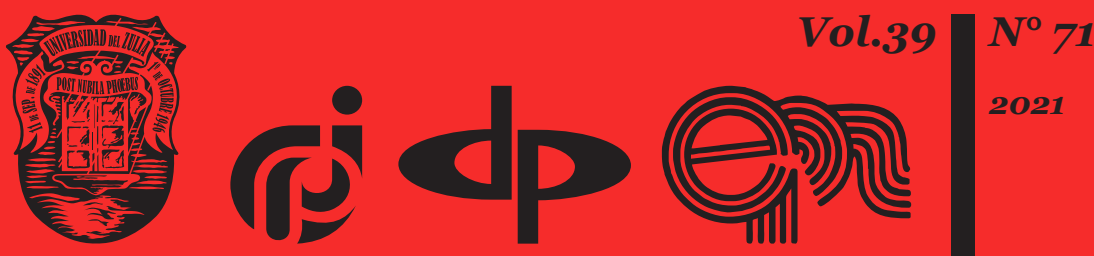


\title{
Application of budget allocation models in the management of investment processes in the context of the digital economy development
}

\author{
DOI: https://doi.org/10.46398/cuestpol.3971.35
}

\author{
Viktoriia Chobitok * \\ Oleg Shevchenko ** \\ Oksana Lomonosova *** \\ Volodymyr Kochetkov **** \\ Valentyna Bykhovchenko *****
}

\section{Abstract}

Within the study, the use of the public-private partnership mechanism in the management of investment processes in the context of digitalization was argued. The methodological basis of the study was a process approach, which allows to study multidirectional investment actions and the interdependent impact of the investment process, which determines the causal links of the development of investment entities at different levels in the collection of resources, in the conditions of the development of the digital economy. Endogenous sources include financial resources of internal and external origin. Exogenous investment resources include financial resources on loan, as well as budgetary allocations. Varieties of budget allocations include government procurement, concession, life cycle contract. Comparativecreativecharacterization of investment resource attraction models was carried out at the expense of budgetary allocations. In conclusion, they highlight the advantages of attracting investment resources at the expense of budgetary allocations, namely the public-private partnership model as a concession. Finally, it carriesout the comparative characteristic

* Doctor of Economic Sciences, Associate Professor, Department of Economics and Management, Ukrainian Engineering and Pedagogical Academy, Kharkiv, Ukraine. ORCID ID: https://orcid. org/oooo-0002-5272-388X

** PhD in Economics, Associate Professor, Department of Management and Civil Service, Chernihiv Polytechnic National University, Chernihiv, Ukraine. ORCID ID: https://orcid.org/oooo-0oo2-27398018

*** Doctor of Economic Sciences, Professor, Department of Economics, Admiral Makarov National University of Shipbuilding, Kherson, Ukraine. ORCID ID: https://orcid.org/oooo-0002-1007-3786

**** Doctor of Economic Sciences, Professor, Department of Business Analytics and Digital Economy, National Aviation University, Kyiv, Ukraine. ORCID ID: https://orcid.org/oooo-0002-5646-7537

***** PhD in Economics, Associate Professor, Department of Production and Investment Management, National University of Life and Environmental Sciences of Ukraine, Kyiv, Ukraine. ORCID ID: https:// orcid.org/oooo-0002-7225-4646 
of the conditions of the implementation of investment projects in various models of attraction of investment resources at the expense of budgetary allocations.

Keywords: budget allocation; state-private partnership; investment processes; investment resources; digital economy.

\section{Aplicación de modelos de asignación presupuestaria en la gestión de procesos de inversión en el contexto del desarrollo de la economía digital}

\section{Resumen}

Dentro del estudio se argumentó el uso del mecanismo de alianza público-privada en la gestión de los procesos de inversión en el contexto de la digitalización. La base metodológica del estudio fue un enfoque de proceso, que permite estudiar acciones multidireccionales de inversión y el impacto interdependiente del proceso de inversión, que determina los vínculos causales del desarrollo de las entidades de inversión a diferentes niveles en la captación de recursos, en las condiciones del desarrollo de la economía digital. Las fuentes endógenas incluyen recursos financieros de origen interno y externo. Los recursos de inversión exógenos incluyen recursos financieros en préstamo, así como asignaciones presupuestarias. Las variedades de asignaciones presupuestarias incluyen contratación pública, concesión, contrato de ciclo de vida. Se realizó la caracterización creativa comparativa de los modelos de atracción de recursos de inversión a expensas de las asignaciones presupuestarias. Como conclusión se destacan las ventajas de atraer recursos de inversión a expensas de las asignaciones presupuestarias, a saber, el modelo de asociación público-privada como concesión. Por ultimo, se lleva a cabo la característica comparativa de las condiciones de la implementación de proyectos de inversión en varios modelos de atracción de recursos de inversión a expensas de las asignaciones presupuestarias.

Palabras clave: asignación de presupuesto; asociación estatal-privada; procesos de inversión; recursos de inversión; economía digital. 
Viktoriia Chobitok, Oleg Shevchenko, Oksana Lomonosova, Volodymyr Kochetkov y Valentyna Bykhovchenko

596

Application of budget allocation models in the management of investment processes in the context of the digital economy development

\section{Introduction}

Current challenges of increasing threats and risks are relevant to the study of the issues related to the attraction of investment resources in the activities of economic entities at the level of microeconomic systems, areas of activity, regions and the state as a whole. This is due to the limited selffinancing of businesses at different levels, global and local threats and risks, the presence of inflation. Changes in the credit and banking, and currency system, fluctuations in energy prices, etc. should be also considered.

Attracting investment resources and the efficiency of their use makes it possible to modernize the production capacity of economic entities of different levels, to increase their profitability, to solve problems of inclusive and sustainable development. The activation of investment processes has a positive effect on economic growth and sustainable development of economic systems at various levels. Attracting investment resources are expressed through the investment of resources to increase the capital of enterprises, areas of activity, regions, state.

The purpose of the study is to justify the use of the mechanism of publicprivate partnership in the management of investment processes in the context of digitalization.

\section{Literature Review}

The study of budget allocations in the management of investment processes, public-private partnerships, and their role in regional development in the context of digitalization is devoted to the scientific achievements of domestic and foreign scientists, namely: Abramova (2021); Ahmad and Raza (2020); Albalate, Bel, Geddes. (2020); Armand (2020); Balykina and Zakharov (2015); Belyaev (2020); Cosmulese (2019); Chen (2021); Dergaliuk et al. (2021); Dubyna et al. (2018); Elwakil and Hegab (2020); Fedyshyn et al. (2019); Fleta-Asín and Muñoz (2021); Garafonova et al. (2021); Grigoraș-Ichim et al. (2018); Kadhim et al. (2020); Khan et al. (2020); Khanin et al. (2021); Kholiavko et al. (2020, 2021); Kychko et al. (2021); Mashnenkov et al. (2021); Popelo (2017); Pravkin et al. (2020); Prokopenko et al. (2018); Qin et al. (2021); Raza et al. (2021); Samiilenko et al. (2021); Samoilovych et al. (2021); Shahbaz et al. (2020); Shevchuk et al. (2021); Shkarlet et al. (2019); Sresakoolchai (2020); Tulchynska et al. (2021); Vovk et al. (2021) and others.

According to the results of the study (Kadhim et al. 2020), the authors concluded that there is a need for constant state support, the constant flow of funding and the search for other sources. According to the authors, this will help prolong the implementation of investment projects and increase 
annual allocations. The authors of the article (Balykina and Zakharov, 2015) have developed a plan support algorithm that can be used to allocate the budget over a period of time based on key performance indicators that are formed in the context of the budget policy framework. The research results of scientists (Chen, 2021) have shown that public-private partnership has significant and positive economic growth and the consequences of spatial space, which can contribute to regional economic integration, embodying its function of economic stability. It is proved that the economic impact of public-private partnership has significant industrial heterogeneity, energy and water public-private partnership have positive externalities.

The authors of the article (Fleta-Asín and Muñoz, 2021) concluded that the support of multilateral development banks has a positive effect on the participation of private investors in public-private partnerships for renewable energy. The authors arguethat government actions that contribute to the institutional financing of third parties, as well as to the improvement of their institutions and the economic environment, contribute to setting priorities through a positive impact on private participation.

The research of the article (Raza et al., 2021) is aimed to focus publicprivate partnerships on renewable energy where it is more efficient. The results of the authors' research will be useful for politicians in developing countries, which will contribute to the rational and effective solution of urgent environmental problems. The authors (Khan et al., 2020) examine the impact of public-private partnership investments in energy and technological innovation on carbon emissions based on the consumption for China. Based on the research, scientists recommend technological innovations for a cleaner production process and public-private partnership investments in renewable energy sources.

The main idea of the study (Ahmad and Raza, 2020) is to examine the impact of public-private partnership investments in energy, technological innovation, economic growth, exports, and foreign direct investment on $\mathrm{CO} 2$ emissions in Brazil. The results of the analysis and the adoption of scientists contribute to the formation of a new view of politicians on the regulation of public-private partnership investments in the energy sector in order to improve the quality of the environment. The importance of publicprivate partnerships is explained (Sresakoolchai, 2020) by the fact that many governments around the world have budget constraints and may try to prioritize their budgets for other events in need. The authors argue that the ability of the private sector to participate in investment is an important aspect of saving for the government. The authors proved that public-private partnership has certain advantages and risks, depending on the phase of the project.

The authors of the study (Albalate et al., 2020) argue that the use of public-private partnerships is an important component in providing the 
Viktoriia Chobitok, Oleg Shevchenko, Oksana Lomonosova, Volodymyr Kochetkov y Valentyna Bykhovchenko

infrastructure. According to researchers, attracting private investment and expanding opportunities contributes to the exemption from property taxes, exemption from current legislation on procurement and protection of confidentiality. Within the research (Pravkin et al., 2020), the use of benefits of public-private partnership is suggested.

The authors emphasize the consideration of regional specifics on the example of the rail freight market as a meso-level institution. Scientists suggest the ways to improve legislation on the development of the freight market based on established guidelines for the development of public-private partnership models in transport projects. The scientists' article (Elwakil and Hegab, 2020) is based on a study of the impact of gross national income and the percentage of the population with access to drinking water on the choice of candidate countries for investing in public-private partnerships in water supply projects. The authors simulated the relationship between gross national income and the percentage of the population with the access to drinking water. To classify countries by investment groups, scientists have developed four models.

\section{Materials and Methods}

The methodological basis of the study. The use of the mechanism of public-private partnership in the management of investment processes in the context of digitalization is a process approach. This is due to the fact that investments are a process of investing in investment objects, in this process, the transformation of the potential of investment entities into capital is highlighted. The process approach makes it possible to study the multidirectional actions of investing, the interdependent impact of the investment process, which determines causal links of the development of investment entities in terms of attracting investment resources in today's growing threats and risks.

The process approach makes it possible to plan, coordinate, optimize and increase the efficiency of investment processes. It also provides an opportunity to simultaneously investigate the impact of the external environment on investment, namely by the state in the form of regulatory, security and protective influence, macroeconomic factors of the development, market economic laws and more.

As a methodological basis, the process approach provides an opportunity to consider the attraction of investment resources as a logical sequence of interrelated actions over time, which, in turn, leads to changes and turns input resources into the end result, which in turn can become an input resource again. 
Also, in the process of studying the use of the mechanism of publicprivate partnership in the management of investment processes in the context of the digital economy development, general economic and specific methods of scientific knowledge are used.

\section{Results}

Investments have been and remain an important and relevant process for the economic development of economic entities at various levels, they contribute to the development of productive forces, increase profits, social, environmental and economic effects. The process of the formation of investment resources and their attraction depends on many factors, including the process of capital accumulation and redistribution, political and financial stability, economic policy of the state, globalization challenges of social development and so on.

Today's challenges of social development require more and more investment at different levels of economic systems. For businesses, the sources of investment resources can be endogenous and exogenous, depending on their origin. Endogenous sources include the own financial resources of economic entities. Such sources include:

- financial resources of internal origin (for example, the profit of the business entity, initial contributions of the founders, etc.).

- external origin (for example, payments of insurance companies, sale of part of assets, additional contributions of share or share capital, etc.).

They have many different advantages, but their main drawback is the limited and insufficient for the further development of the economic entity at different levels. And this is the main incentive to attract investment resources from exogenous sources.

If we consider in more detail the investment resources of exogenous approval in relation to the entity, they can also be divided into several components such as (Fig. 1):

firstly, attracted financial resources (for example, from the sale of securities, equity and other contributions of legal entities and individuals, venture capital, factoring operations, sales, etc.);

secondly, borrowed financial resources (for example, types of lending, bond loans, investments of non-bank financial institutions, etc.);

thirdly, budget allocations (the participation of budget funding at the level of state or local budgets using different models of public-private partnership is considered). 
Viktoriia Chobitok, Oleg Shevchenko, Oksana Lomonosova, Volodymyr Kochetkov y Valentyna Bykhouchenko

Application of budget allocation models in the management of investment processes in the context of the digital economy development

SOURCES OF ATTRACTING INVESTMENT RESOURCES BY BUSINESS ENTERPRISES OF DIFFERENT LEVELS

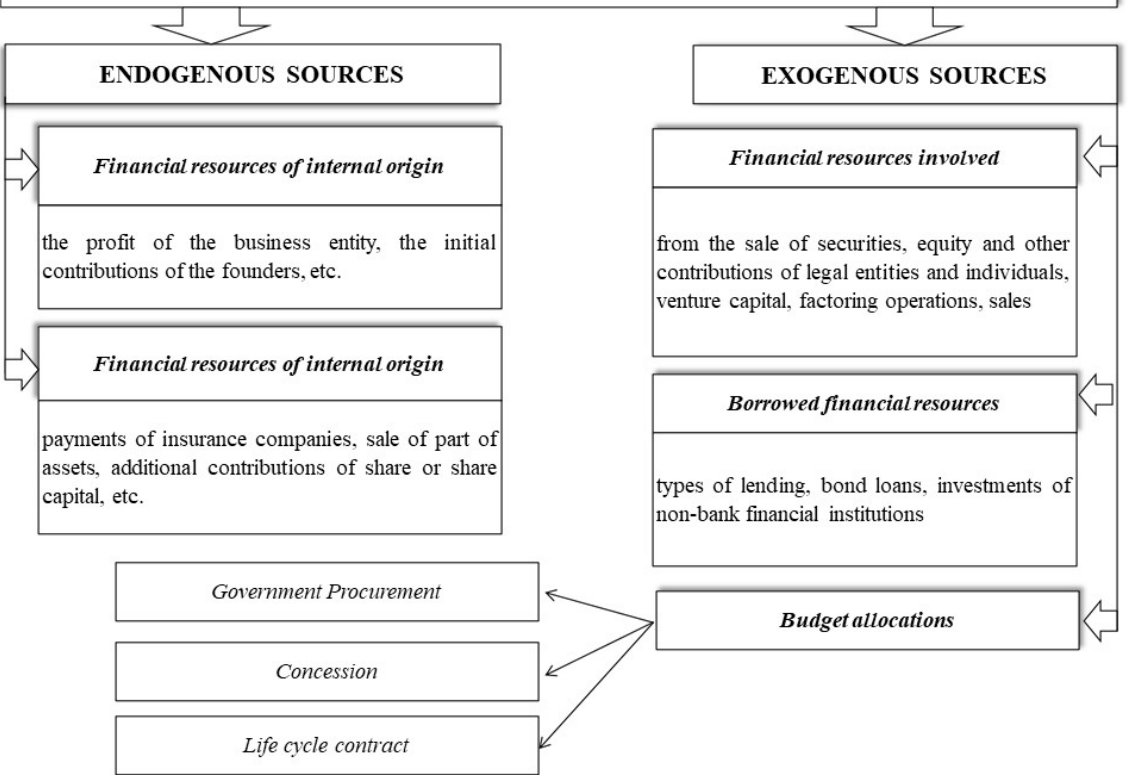

Fig. 1. Varieties of sources of investment resources by economic entities of different levels. Source: suggested by the authors

If we dwell in more detail on budget allocations, the most commonly used models of interaction between private business and public partner are:

- $\quad$ public procurement, including deferred public procurement, in which case financing is provided by the public sector through redistribution of budget funds, debt financing or in the form of soft loans from institutional or commercial banks with the participation of a state guarantee. It should be noted that this model of investment is gradually, as the world experience shows, ceases to be widespread. This is due to the processes of the power decentralization, the reduction of revenues to central budgets and the emergence of more effective models for attracting budget allocations;

- concession, the main essence of this investment model is to transfer the main commercial risks to the concessionaire, namely the risks associated with the level of income from the use of goods and services by the final consumer; 
- life cycle contract, in this investment model the risk of demand remains with the public partner, and the private partner implements all stages of the life cycle of the investment project, including the operation and maintenance of the project object;

- combinations of the previous investment models using budget allocations.

- Comparative characteristics of investment models of budget allocations in the context of digitalization are presented in Table 1.

Table 1. Comparative criteria characteristics of models for attracting investment resources through budget allocations in the context of digitalization

\begin{tabular}{|c|c|c|c|}
\hline \multirow{2}{*}{$\begin{array}{l}\text { Criterion for } \\
\text { comparing budget } \\
\text { allocation models }\end{array}$} & \multicolumn{3}{|c|}{ Model } \\
\hline & $\begin{array}{c}\text { state } \\
\text { purchases }\end{array}$ & concession & $\begin{array}{l}\text { life cycle } \\
\text { contract }\end{array}$ \\
\hline $\begin{array}{l}\text { Terms of the preparation } \\
\text { of the investment project } \\
\text { (months) }\end{array}$ & $\begin{array}{l}\text { 12-24 months } \\
\text { when attracting } \\
\text { a loan, } 3-6 \\
\text { months when } \\
\text { deferred } \\
\text { payment under a } \\
\text { state guarantee }\end{array}$ & $12-36$ & $12-24$ \\
\hline $\begin{array}{l}\text { Percentage of budget } \\
\text { financing of the total cost } \\
\text { of the investment project } \\
\text { (\%) }\end{array}$ & 100 & $50-80$ & $\begin{array}{c}100 \text { less } \\
\text { compensatory } \\
\text { business }\end{array}$ \\
\hline $\begin{array}{l}\text { Percentage of attracted } \\
\text { private partner funds } \\
\text { from the total cost of the } \\
\text { investment project }(\%)\end{array}$ & o & $50-20$ & $\begin{array}{l}\text { in the } \\
\text { volume of } \\
\text { compensatory } \\
\text { business }\end{array}$ \\
\hline $\begin{array}{l}\text { Percentage of state } \\
\text { guarantees, from the total } \\
\text { cost of the investment } \\
\text { project (\%) }\end{array}$ & 100 & $10-20$ & $\begin{array}{c}\text { 10o less } \\
\text { compensatory } \\
\text { business }\end{array}$ \\
\hline $\begin{array}{l}\text { The core of finding the } \\
\text { risks of the investment } \\
\text { project }\end{array}$ & state customer & $\begin{array}{l}\text { balance of risks } \\
\text { between public } \\
\text { and private } \\
\text { partner }\end{array}$ & public partner \\
\hline $\begin{array}{l}\text { Deviation of investment } \\
\text { project costs from the } \\
\text { planned level in capital } \\
\text { expenditures (\%) }\end{array}$ & $30-50$ & $3-5$ & $5^{-10}$ \\
\hline $\begin{array}{l}\text { Deviation of investment } \\
\text { project costs from the } \\
\text { planned level in operating } \\
\text { costs (\%) }\end{array}$ & $30-40$ & Has no data & $10-15$ \\
\hline
\end{tabular}


The presented in Table 1 criterion comparison of models of the attraction of investment resources at the expense of budgetary allocations gives a chance to state that each model has the unconditional advantages and lacks. Thus, according to the model of public procurement, the center of finding the risks of the investment project is the state customer, which reduces the risks of the private partner. Given the application of the life cycle contract model, on the contrary, the main burden of risk falls on the public partner. The public procurement model has a very limited range of involvement in investment processes and very long deadlines for signing agreements and preparing contracts.

But, as already noted, the global trend of attracting investment resources through budget allocations has moved away from the model of public procurement. This is due to the fact that attracting investment resources through such models of public-private partnership as a concession has certain advantages, including:

- a possibility of using the latest innovative technologies owned by the private sector;

- distribution of investment risks in the direction of their transfer to a private partner who has more experience and higher efficiency of such risk management, which, in turn, helps to obtain the effect of value for money in such risk distribution;

- reducing the cost of investment projects through the use of optimal, innovative, creative technologies and motivation of the private partner to reduce investment and the compliance with time periods of its implementation;

- financing of capital investments at the expense of private, not public funds, which reduces the burden on the budgets of different levels;

- maximum reduction of the deviation of investment project costs from the planned level.

Also, the use of the public-private partnership model to attract investment projects has many other advantages over the model of public procurement, which is presented in Table 2. 
Table 2: Comparative characteristics of the conditions for the implementation of investment projects for different models of attracting investment resources through budget allocations in the conditions of digitalization

\begin{tabular}{|c|c|c|}
\hline $\begin{array}{l}\text { Conditions } \\
\text { for financing } \\
\text { an investment } \\
\text { project }\end{array}$ & $\begin{array}{l}\text { Due to budget financing } \\
\text { (public procurement) }\end{array}$ & $\begin{array}{l}\text { Due to the use of public- } \\
\text { private partnership } \\
\text { (concession) }\end{array}$ \\
\hline $\begin{array}{l}\text { Technological } \\
\text { risk management }\end{array}$ & $\begin{array}{l}\text { A high level of the effective } \\
\text { technological risk management is } \\
\text { not achieved due to the gap in the } \\
\text { competencies of the private sector }\end{array}$ & $\begin{array}{l}\text { High level of the technological } \\
\text { risk management because the } \\
\text { private partner directly takes } \\
\text { care of them at all stages of the } \\
\text { investment project }\end{array}$ \\
\hline $\begin{array}{l}\text { The cost of the } \\
\text { investment } \\
\text { project }\end{array}$ & $\begin{array}{l}\text { There are no motivating factors to } \\
\text { reduce the cost of the investment } \\
\text { project, and can be increased in the } \\
\text { presence of a corruption component } \\
\text { of public administration }\end{array}$ & $\begin{array}{l}\text { Motivates to reduce the cost of } \\
\text { the investment project in terms } \\
\text { of using the model of attracting } \\
\text { investment resources through } \\
\text { public-private partnership }\end{array}$ \\
\hline $\begin{array}{l}\text { Volumes of state } \\
\text { funding }\end{array}$ & $\begin{array}{l}\text { The design and construction of the } \\
\text { investment project is fully financed } \\
\text { by investments from the state } \\
\text { (local) budget }\end{array}$ & $\begin{array}{l}\text { Capital expenditures on the } \\
\text { investment project are financed } \\
\text { by a private partner with partial } \\
\text { state financing or state crediting } \\
\text { and guaranteeing }\end{array}$ \\
\hline $\begin{array}{l}\text { Use of innovative } \\
\text { technologies }\end{array}$ & $\begin{array}{l}\text { Lack of motivation to use } \\
\text { innovative technologies as there is } \\
\text { no motivation to reduce the cost } \\
\text { of the project and attract the latest } \\
\text { technological solutions }\end{array}$ & $\begin{array}{l}\text { Private partner is interested in } \\
\text { using innovative technologies } \\
\text { to ensure a balance of value and } \\
\text { quality of the investment project }\end{array}$ \\
\hline $\begin{array}{l}\text { Transfer of risks } \\
\text { of investment } \\
\text { projects }\end{array}$ & $\begin{array}{l}\text { Risk transfer is not used, i.e., the } \\
\text { effect of price-quality ratio is not } \\
\text { achieved due to risk transfer }\end{array}$ & $\begin{array}{l}\text { With a reasonable distribution of } \\
\text { risks on the investment project, } \\
\text { the effect of value for money is } \\
\text { achieved }\end{array}$ \\
\hline $\begin{array}{l}\text { Reduction } \\
\text { of terms } \\
\text { (construction, } \\
\text { reconstruction) } \\
\text { for the } \\
\text { investment } \\
\text { project }\end{array}$ & $\begin{array}{l}\text { There is no reduction in the } \\
\text { terms of the investment project } \\
\text { because there are no motivational } \\
\text { mechanisms for this, and often } \\
\text { the deadlines are increased due to } \\
\text { delays in budget allocations }\end{array}$ & $\begin{array}{l}\text { Motivational factors using } \\
\text { public-private partnerships } \\
\text { help to reduce the time of } \\
\text { implementation of investment } \\
\text { projects }\end{array}$ \\
\hline $\begin{array}{l}\text { Gradual state } \\
\text { financing of } \\
\text { the investment } \\
\text { project }\end{array}$ & $\begin{array}{l}\text { The state financing of the } \\
\text { investment project occurs at all } \\
\text { its stages from designing to its } \\
\text { implementation, financing is } \\
\text { carried out for a short period of } \\
\text { time. }\end{array}$ & $\begin{array}{l}\text { The state partially finances the } \\
\text { creation of an object to attract } \\
\text { investment resources, as well } \\
\text { as pays service fees for services } \\
\text { related to quality infrastructure, } \\
\text { distributed over the entire life of } \\
\text { the investment project. Deadlines } \\
\text { can be reduced by the amount of } \\
\text { payment received from end users, } \\
\text { when transferring such a function } \\
\text { from the state to a private partner }\end{array}$ \\
\hline
\end{tabular}

Source: suggested by the authors.

The presented comparative characteristic (Table 2) of attracting investment resources under different models of budget allocations clearly 
Viktoriia Chobitok, Oleg Shevchenko, Oksana Lomonosova, Volodymyr Kochetkov y Valentyna Bykhovchenko

604

Application of budget allocation models in the management of investment processes in the context of the digital economy development

in the conditions of digitalization demonstrates the greater attractiveness of using the model of public-private partnership compared to public procurement. The mechanism of public-private partnership involvement has strong positive effects for all participants of investment projects both for state (local) authorities and for the private partner, as well as for the final consumer, as it can receive timely and higher quality services and products due to the use of innovative technologies in the investment project.

At the same time, it should be noted that the model of attracting investment resources has negative factors of its implementation that accompany any complex process. Negative factors include a significant political influence and lobbying of the interests of different political elites on the institutional basis and the procedure for regulating the objects of attracting investment resources. This issue is especially acute when the country is experiencing political turmoil, changes in the Government and the Cabinet of Ministers, reforming the political system and economic regulation, legitimate procedures for reviewing and revoking previous decisions to attract investment resources and signing public-private partnership agreements. Also, the facts of bureaucracy and corruption, the shadowing of the economy, can negatively affect the attraction of investment resources and the interaction of public-private partners, lead to an increase in the cost of investment projects.

\section{Conclusion}

Thus, the use of such a budget allocation model as a public-private partnership has significant positive effects over other models, such as public procurement. This is due to the fact that public-private partnership makes it possible to reduce the cost of providing services to consumers, develops various creative forms of project financing, establishes closer relationships between the authorities at different levels and private partners and businesses. The mechanism of attracting investment resources using the model of public-private partnership gives other indirect effects in the form of increasing employment, reducing the cost of services, including socially significant, helps to solve environmental problems.

The scientific novelty of this study is that based on the process approach to attracting investment resources and highlighting the criteria characteristics of budget allocation models justify the principles of using the mechanism of public-private partnership in managing investment processes in the context of digital economy development.

Further research requires the activation of power structures at various levels to intensify the attraction of investment resources through the model of public-private partnership. 


\section{Bibliographic References}

ABRAMOVA, Alla; SHAPOSHNYKOV, Kostiantyn; ZHAVORONOK, Artur; LIUTIKOV, Pavlo; SKVIRSKYI, Illia; LUKASHEV, Oleksandr. 2021. "Ecosystem of VAT Administration in E-Commerce: Case of the Eastern Europe Countries" In: Estudios de economía aplicada. Vol. 39, No. 5, pp. 3-19.

AHMAD, Mahmood; RAZA; Muhammad Yousaf. 2020. "The role of publicprivate partnerships investment in energy and technological innovations in driving climate change: evidence from Brazil" In: Environmental Science and Pollution Research. Vol. 27, No. 24, pp. 30638-306481.

ALBALATE, Daniel; BEL, Germà; GEDDES, Richard. 2020. "Does PublicPrivate-Partnership enable laws to increase private investment in transportation infrastructure?” In: Journal of Law and Economics. Vol. 63, No. 1, pp. 43-70.

ARMAND, Jasmine. 2020. "Establishing economic independence in Haiti through public-private partnerships and foreign direct investments" In: Northwestern Journal of International Law and Business. Vol. 40, No. 3 , pp. 363-390.

BALYKINA, Yulia; ZAKHAROV, Victor. 2015. "Budget allocation planning for multi-sectoral investments" In: 2015 International Conference on "Stability and Control Processes" in Memory of V.I. Zubov, SCP 2015 Proceedings, pp. 452-454.

BELYAEV, Y.M; OGANESYAN, T.L; ARYTYUNOVA, A.E. 2020. "Mechanisms of public-private partnership and ensuring innovation and investment activities in the region" In: IOP Conference Series: Earth and Environmental Science. Vol. 650 (12021), Art. 012035.

CHEN, Bingyao. 2021. "Public-private partnership infrastructure investment and sustainable economic development: An empirical study based on efficiency evaluation and spatial spillover in China" In: Sustainability. Vol. 13, No. 15, Art. 8146.

COSMULESE, Cristina Gabriela; GROSU, Veronica; HLACIUC, Elena; ZHAVORONOK, Artur. 2019. "The Influences of the Digital Revolution on the Educational System of the EU Countries" In: Marketing and Management of Innovations. Vol. 3, pp. 242-254.

DERGALIUK, Marta; KHANIN, Semen; POPELO, Olha; TULCHYNSKA, Svitlana; PAKHOTA, Nataliia. 2021. "Intensification of the development of regional economic systems in the conditions of the creative economy 
Viktoriia Chobitok, Oleg Shevchenko, Oksana Lomonosova, Volodymyr Kochetkov y Valentyna Bykhovchenko

606

Application of budget allocation models in the management of investment processes in the context of the digital economy development

formation" In: Laplage em Revista (International). Vol. 7, No. 3, pp. 8088.

DERHALIUK, Marta; POPELO, Olha; TULCHYNSKA, Svitlana; MASHNENKOV, Kostyantyn; BEREZOVSKYI, Danylo. 2021. "State policy of the potential-forming space transformation in the context of the regional development intensification” In: CUESTIONES POLÍTICAS. Vol. 39, No. 70, pp. 80-93.

ELWAKIL, Emad; HEGAB, Mohamed. 2020. "Investment possibility-based models for public-private partnerships in water projects" In: Canadian Journal of Civil Engineering. Vol. 47, No. 4, pp. 461-469.

FEDYSHYN, Maiia; ABRAMOVA, Alla; ZHAVORONOK, Artur; MARYCH, Maksym. 2019. "Management of competitiveness of the banking services" In: Financial and credit activity: problems of theory and practice. Vol. 1, No. 28, pp. 64-74.

FLETA-ASÍN, Jorge; MUÑOZ, Fernando. 2021. "Renewable energy publicprivate partnerships in developing countries: Determinants of private investment” In: Sustainable Development. Vol. 29, No. 4, pp. 653-670.

GRIGORAŞ-ICHIM, Claudia-Elena; COSMULESE, Cristina Gabriela; SAVCHUK, Dmytro; ZHAVORONOK, Artur. 2018. "Shaping the perception and vision of economic operators from the Romania Ukraine - Moldova border area on interim financial reporting" In: Economic Annals-XXI. Vol. 173, No. 9-10, pp. 60-67.

KADHIM, Maytham Abed; MERHEJ, Basim Mohammed; ABDULAH, Abdulamer Jbar. 2020. "The effect of declining financial allocations and government funding on the financial achievement of projects implemented in the investment plan budget (an applied study on AlMuthanna University's investment projects)" In: International Journal of Innovation, Creativity and Change. Vol. 12, No. 7, pp. 23-42.

KHAN, Zeeshan; ALI, Muhsin; KIRIKKALELI, Dervis; WAHAB, Salman; JIAO, Zhilun. 2020. "The impact of technological innovation and public-private partnership investment on sustainable environment in China: Consumption-based carbon emissions analysis" In: Sustainable Development. Vol. 28, No. 5, pp. 1317-1331.

KHANIN, Semen; AREFIEVA, Olena; DERGALIUK, Marta; POPELO, Olha; TULCHYNSKA, Svitlana. 2021. "Concepts of the activation of intellectual and innovative determinants for the development in order to intensify the introduction of the regional economic systemsn" In: Laplage em Revista (International). Vol. 7, No. Extra E, pp. 234-244. 
KHOLIAVKO, Nataliia; DJAKONA, Antonina; DUBYNA, Maksym; ZHAVORONOK, Artur; LAVROV, Ruslan. 2020. "The higher education adaptability to the digital economy" In: Bulletin of the National Academy of Sciences of the Republic of Kazakhstan. Vol. 4, No. 386, pp. 294-306.

KHOLIAVKO, Nataliia; POPELO, Olha; DUBYNA, Maksym; PANCHENKO, Olena; TARASENKO, Artem; KOZLIANCHENKO, Olena. 2021. "Criteria for the description of the financial behavior model of households in the digitalization conditions" In: Laplage em Revista (International). Vol. 7, No. 3B, pp. 57-67.

KYCHKO, Iryna; SAMIILENKO, Halyna; KHUDOLEI, Veronika; BONDAR, Nataliia; KRAVCHYK, Yurii. 2021. "Risks of Digital Transformations of labour relations and the labour market" In: Laplage em Revista (International). Vol. 7, No. Extra E, pp. 650-660.

POPELO, Olha. 2017. "Methodological approaches to modernization processes of the productive forces in the conditions of Eurointegration" In: Scientific Bulletin of Polissia Vol. 1, No. 1-9, pp. 218-224.

POPELO, Olha; GARAFONOVA, Olga; TULCHYNSKA, Svitlana; DERHALIUK, Marta; BEREZOVSKYI, Danylo. 2021. "Functions of public management of the regional development in the conditions of digital transformation of economy” In: Amazonia Investiga. Vol. 10, No. 43, pp. 49-58.

PRAVKIN, Sergei; SMIRNOVA, Vera; SHAGIEVA, Rosalina; ARKHIPOV, Igor; EROFEEVA, Diana. 2020. "Meso-level investment management in transport projects with the application of the public-private partnership mechanism" In: E3S Web of Conferences. Vol. 208, Art. 06019.

QIN, Shikun; LUO, Weijie; WANG, Yaling. 2021. "Policy uncertainty and the company-level investment: evidence from public-private partnership market in China" In: Applied Economics Letters.

RAZA, Syed Ali; SHAH, Syed Hasanat; YOUSUFI, Sara Qamar. 2021. "The impact of public-private partnerships. Investment in Energy on carbon emissions: evidence from nonparametric causality-in-quantiles" In: Environmental Science and Pollution Research. Vol. 28, Vol. 18, pp. 23182-23192.

SAMIILENKO, Halyna; POPELO, Olha; KHUDOLEI, Veronika; MASHNENKOV, Kostyantyn; DERKACHENKO, Yuliia. 2021. "Transformational processes of clustering in digital economy" In: Laplage em Revista (International). Vol. 7, No. Extra C, pp. 691-702.

SAMOILOVYCH, Anastasia; GARAFONOVA, Olga; POPELO, Olha; MARHASOVA, Viktoriya; LAZARENKO, Yuliia. 2021. "World experience and ukrainian realities of digital transformation of regions in the context 
Viktoriia Chobitok, Oleg Shevchenko, Oksana Lomonosova, Volodymyr Kochetkov y Valentyna Bykhovchenko

608

Application of budget allocation models in the management of investment processes in the context of the digital economy development

of the information economy development" In: Financial and credit activity: problems of theory and practice. Vol. 3, No. 38, pp. 316-325.

SHAHBAZ, Muhammad; RAGHUTLA, Chandrashekar; SONG, Malin; ZAMEER, Hashim; JIAO, Zhilun. 2020. "Public-private partnerships investment in energy as new determinant of $\mathrm{CO} 2$ emissions: The role of technological innovations in China” In: Energy Economics. Vol. 86, Art. 104664 .

SHKARLET, Serhii; DUBYNA, Maksym; ZHUK, Olena. 2018. "Determinants of the financial services market functioning in the era of the informational economy development" In: Baltic Journal of Economic Studies. Vol. 4, No. 3, pp. 349-357.

SHKARLET, Serhii; KHOLIAVKO, Nataliia; DUBYNA, Maksym; ZHUK, Olena. 2019. "Innovation, educational, research components of the evaluation of information economy development (as exemplified by eastern partnership countries)" In: Marketing and Management of Innovations. Issue 1 , pp. 70-83.

SHKARLET, Serhii; PROKOPENKO, Valeriia; DUBYNA, Maksym. 2018. "Directions of development of the financial services market of Ukraine" In: Baltic Journal of Economic Studies. Vol. 4, No. 5, pp. 412-420.

SRESAKOOLCHAI, Jessada; KAEWUNRUEN, Sakdirat. 2020. "Comparative studies into public private partnership and traditional investment approaches on the high-speed rail project linking 3 airports in Thailand" In: Transportation Research Interdisciplinary Perspectives. Vol. 5, Art. 100116.

TULCHYNSKA, Svitlana; POPELO, Olha; DERGALIUK, Bogdan; KHANIN, Semen; SHEVCHUK, Nataliia. 2021. "Strategic assessment of the ecological condition of the regions in the context of innovative development” In: Laplage em Revista (International). Vol. 7, No. Extra D, pp. 315-322.

TULCHYNSKA, Svitlana; POPELO, Olha; KOVALENKO, Nataliia; MAKALIUK, Iryna; TUR, Olena. 2021. "Introductuction of the organizational and economic mechanism of the activation of intellectual and innovative determinants of the regional economic development" In: Laplage em Revista (International). Vol. 7, No. 3A, pp. 92-102.

VOVK, Olha; TULCHYNSKA, Svitlana; POPELO, Olha; TULCHINSKIY, Rostislav; TKACHENKO, Tetiana. 2021. "Economic and Mathematical Modeling of the Integration Impact of the Modernization on Increasing the Enterprise Competitiveness" In: Management Theory and Studies for Rural Business and Infrastructure Development. Vol. 43, No. 3, pp. 383-389. 

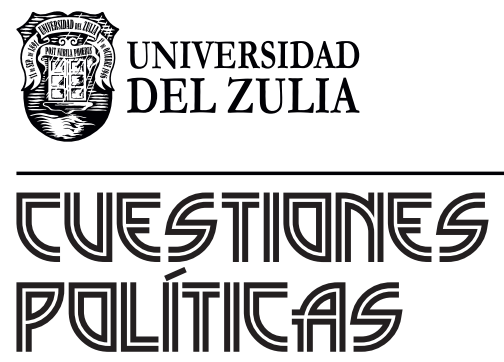

Vol. 39 N $^{\circ} 71$

Esta revista fue editada en formato digital y publicada en diciembre de 2021, por el Fondo Editorial Serbiluz, Universidad del Zulia. Maracaibo-Venezuela 